\title{
A remarkable dropstone from the Wessex Formation (Lower Cretaceous, Barremian) of the Isle of Wight, southern England.
}

\author{
Steven C. Sweetman ${ }^{\mathrm{a},{ }^{*}}$ and Matthew Goodyear ${ }^{\mathrm{b}}$ \\ anniversity of Portsmouth, School of Earth and Environmental Sciences, Burnaby Building, Burnaby \\ Road, Portsmouth PO1 3QL, UK. \\ ${ }^{\mathrm{b}}$ Apartment 6, 1 Whitecroft Park, Tennyson Rise, Sandy Lane, Newport, Isle of Wight PO30 3BY, UK. \\ "Corresponding author. Tel.: +447860 499851 \\ E-mail address: steven.sweetman@port.ac.uk (S.C. Sweetman)
}

\section{ABSTRACT}

A remarkably large, derived, metamorphic clast of Palaeozoic aspect weighing approximately $20 \mathrm{~kg}$ was recently recovered from a plant debris bed occurring in the Lower Cretaceous (Barremian), fluvial, lacustrine and terrestrial Wessex Formation exposed on the south-west coast of the Isle of Wight, southern England. It is interpreted as a dropstone transported in tree roots from a source locality on the Cornubian Massif. During the Early Cretaceous the eastern extremity of this has been estimated to be some $110 \mathrm{~km}$ to the west of the collection locality. Polished extrabasinal clasts of similar lithology are commonly encountered in the Wessex Formation but all recorded to date are much smaller and the majority have been interpreted as gastroliths, although some must be dropstones. The occurrence of this clast demonstrates long distance, floating transport of large root systems and therefore the potential to transport, over long distances, some of the logs and dinosaur remains encountered in the Wessex Formation. Direct evidence for this has been lacking until now and it suggests that some of the dinosaurs recorded from the Wessex Formation may not have been floodplain residents or visitors.

Keywords:

Dropstone

Early Cretaceous

Gastrolith

Hornfels

Wealden

Wessex Formation

\section{Introduction}

Extrabasinal clasts, many of which are polished, are commonly encountered in the entirely non-marine, Lower Cretaceous (Barremian), Wessex Formation of the Isle of Wight, southern England. Most comprise chert and other quartzose lithologies of Palaeozoic aspect, some displaying obvious metamorphic fabrics. They occur in all lithologies but when found in fine-grained deposits, reflecting deposition in low energy environments, they must represent either gastroliths (Mayne, 1854; White, 1921, p. 18; Wings, 2007) or clasts transported to the site of occurrence in floating vegetative systems (Bennett et al., 1996; Martill and Naish, 2001, pp 321-322). However, the latter 
authors discount vegetative transport and to date no allochthonous carbonaceous root systems have been observed in fine-grained strata of the Wessex Formation (SCS pers. obs.). This is perhaps unsurprising as other organic fossils, including vertebrate remains, are also extremely uncommon and often poorly preserved in these deposits. This reflects low preservation potential as footprints and other sedimentary structures representing these created by the large vertebrate fauna are abundant throughout the Formation (Sweetman and Insole, 2010; Pond et al., 2014). In contrast, plant and animal fossils of all sizes are abundant in the plant debris beds of the Wessex Formation (Sweetman and Insole, 2010). However, while logs up to $500 \mathrm{~mm}$ in diameter occur in some, possible root systems associated with these have not been observed and none of the very few smaller root systems observed in a study commenced in 2002 have incorporated rock fragments of any kind (SCS pers. obs.). Nevertheless, the fact that some extrabasinal clasts were transported in tree roots is evidenced by the occurrence of a large cobble-sized fragment of fossiliferous Lower Jurassic calcareous mudstone weighing c. $3.75 \mathrm{~kg}$ and measuring $165 \times 150 \times 85 \mathrm{~mm}$. This was recovered from a fine-grained point bar deposit situated some $98 \mathrm{~m}$ below the top of the Wessex Formation exposed near Grange Chine on the south-west coast of the Isle of Wight (Radley, 1993), (Fig. 1). The source of this clast cannot be ascertained with certainty but Radley (1993) concluded that it may have been derived from an exposure of Lower Jurassic strata in west Dorset. However, the occurrence of derived Jurassic fossils in the overlying Vectis Formation (Radley et al. 1998) suggests that this clast may have had a local source although the extreme paucity of derived Jurassic fossils in the Wessex Formation argues against this (see Sweetman and Underwood 2006, p. 462 for discussion).

This account documents the occurrence of a very large and currently unique extrabsinal clast in a generally low energy fluvial depositional environment. Its petrology is described and conclusions drawn with regard to its possible source. Implications with regard to the palaeoecology of dinosaurs recorded from the Wessex Formation are also discussed.

Institutional abbreviation: IWCMS, Isle of Wight County Museum Service.

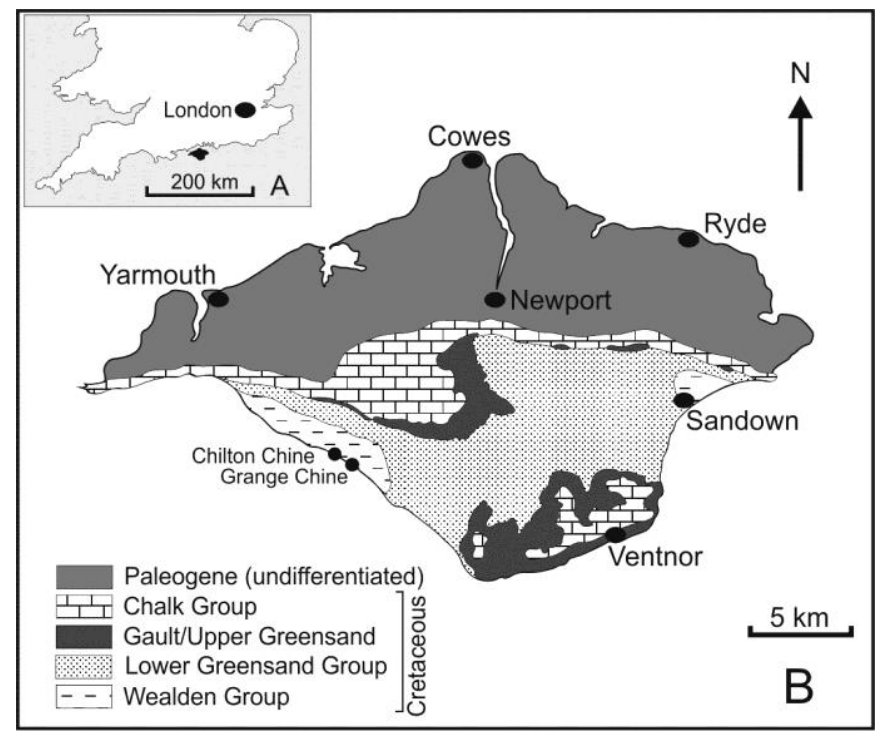

Fig. 1. A, location map. B, outline geological map of the Isle of Wight showing Grange Chine, and Chilton Chine from close to which the described specimen was obtained. 


\section{Geological Setting}

The Wealden Group of the Isle of Wight comprises fluvial, lacustrine and terrestrial deposits of the Barremian Wessex Formation and overlying lagoonal strata of the Barremian to earliest Aptian Vectis Formation (see Sweetman, 2011 and references therein for a comprehensive summary). These are exposed in the cores of anticlines occurring in the south-east and south-west of the Isle of Wight (Fig. 1). The maximum exposed thickness of the Wessex Formation is seen on the south-west coast and is about $180 \mathrm{~m}$ (Stewart, 1978). Here the base of the exposed succession lies at or close to the Hauterivian/Barremian boundary (Harding, 1986; Hughes and McDougall, 1990).

The bulk of the succession was deposited by a perennial, high-sinuosity river system flowing from west to east across a relatively narrow, low relief, fault bounded valley (Stewart, 1978). Petrographic, heavy mineral and palaeocurrent data support sediment derivation from the Armorican and Cornubian Massifs to the south and west respectively (Stewart, 1978; Allen, 1998, Hopson et al., 2008) (Fig. 2). During the Early Cretaceous crustal extension was taking place in response to opening of the proto-Atlantic Ocean. This reactivated faults in Variscan basement rocks. These faults occupy the central part of the Isle of Wight and parts of Dorset as they are today. Subsidence took place to the south of the fault zone providing accommodation for sediment deposited by the river system (Chadwick, 1985; Underhill, 2002). Normal movement on these faults was generally progressive rather than sporadic (Sweetman and Underwood, 2006). However, fluid escape structures (Sweetman, 2011, p.57, Text-fig. 4.5A) and slumped bedding at some horizons, including the plant debris bed from which the specimen described here was obtained, may indicate occasional seismic activity.

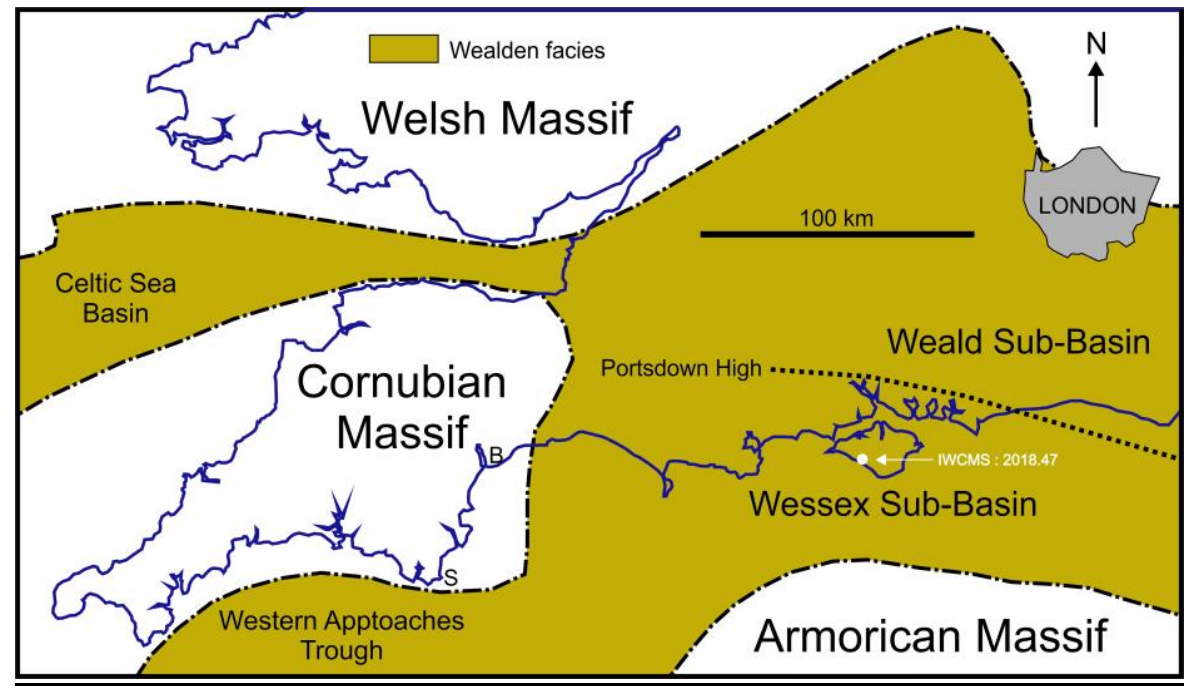

Fig. 2. Palaeogeographical map of southern Britain during the earliest Cretaceous superimposed upon the current coastline and showing the locality from which IWCMS : 2018.47 was recovered. Based on a reconstruction by Hopson et al., 2008 with eastern basin terminology following that of Batten, 2011.

Plant debris beds comprise intrabasinal debris flows created by flash floods occurring soon after forest fires (Sweetman and Insole, 2010). They are a minor component of the Wessex 
Formation (Stewart, 1978) but are the main source of plant and animal fossils. The debris flows responsible for their deposition were localised but were powerful enough to transport, over short distances, very large objects including the largest dinosaur bones and tree trunks. It was from one of these, bed L5 (Stewart, 1978) exposed approximately 50 m south-east of Chilton Chine (Fig. 1) at National Grid Reference SZ 41008209 that the described specimen was obtained. It is accessioned in the collections of the Isle of Wight County Museum Service under accession number IWCMS : 2018.47. The clast was found in situ (by MG) and while it has been cleaned to reveal details of its lithology small amounts of the enclosing matrix have been retained. This comprises grey clay and siderite cemented conglomeratic material typical of the basal part of the bed (Fig. 3). No plant material that might be interpreted as tree roots was found in association with the specimen. This indicates that it was dropped on the floodplain at a time of flood or deposited there together with enclosing roots. In the case of the latter these were later lost to insect activity and/or decay and/or disassociation from the specimen at the time it was incorporated into the debris flow and transported to its final place of burial. The large number of termite coprolites observed in residues obtained from the plant debris beds for the purpose of recovering microvertebrate remains suggest that termite activity may have been a significant factor concerning the destruction of plant remains on the floodplain (Sweetman and Insole, 2010). Furthermore, the poor state of preservation of some vertebrate remains obtained from the plant debris beds suggests that they and other organic material were often subject to long periods of subaerial exposure prior to final burial. This would have permitted complete degradation of less durable plant material (Sweetman and Insole, 2010).

\section{Description}

The specimen (Fig. 3), with accession number IWCMS : 2018.47, weighs c. $20 \mathrm{~kg}$. It is well rounded although of irregular shape. It comprises a very hard, well sorted, fine-grained, metamorphosed, laminated mudstone in which somewhat coarser-grained laminae are quartz-rich (Fig. 4). It is of generally dark grey colour with quartz veining, and in one aspect (Fig $3 \mathrm{~A}$ ) this dominates the lower part of the specimen as shown. Its globular appearance here and the occurrence of discrete and less globular fragments of a vein (Fig. 3A, arrowed) suggest brecciation of first phase mineralisation during a second phase of deformation and metamorphism.

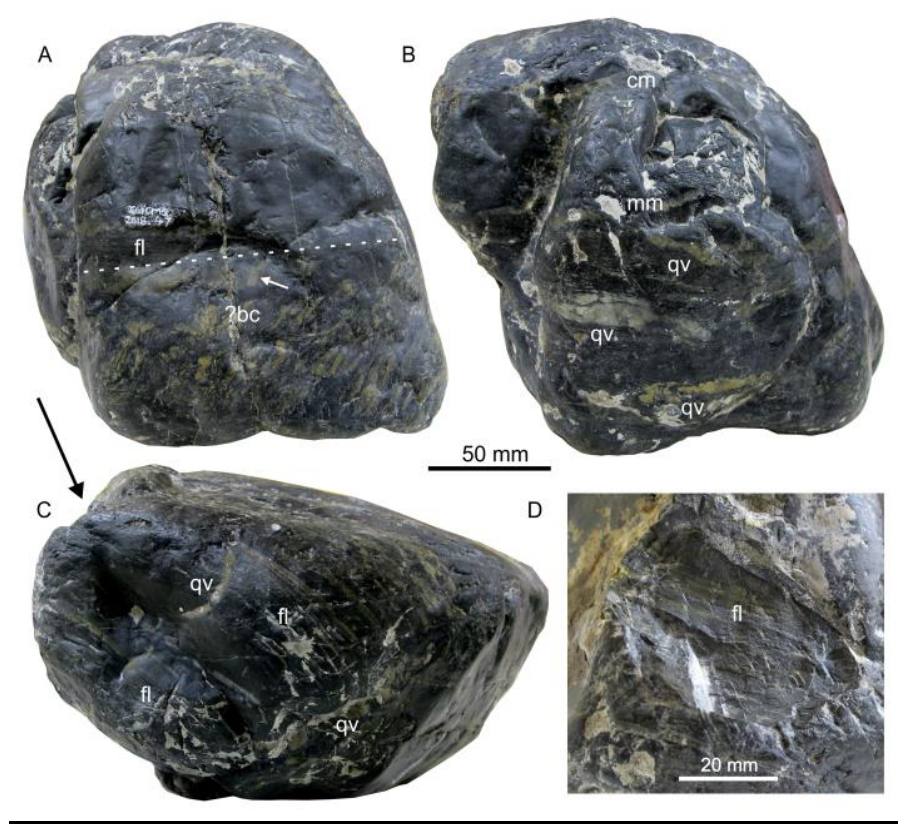


Fig. 3. IWCMS : 2018.47. A, a view to show possible brecciation of first phase quartz veining by second phase deformation and metamorphism. Arrow marks isolated quartz vein fragments. $B, a$ view to show quartz veining and remnants of the enclosing matrix. $C$, a view to show fine dark, clayrich and light quartz-rich laminations. Arrow marks the area from which samples were obtained for the purpose of preparing thin sections. D, close-up view of the sample area showing fine laminations and the subconchoidal to jagged fracture surface. Abbreviations: ?bc, area of possibly brecciated first phase quartz veining. Dotted line delineates this from the finely laminated area above; $\mathrm{cm}$, conglomeratic matrix; $\mathrm{fl}$, fine laminations; $\mathrm{mm}$, mudstone matrix; qv, quartz veining.

The continuous foliation observed in thin sections prepared from one part of the specimen (Fig. 3C, D; Fig. 4) is consistent with sub-greenschist facies regional metamorphism. However, this foliation may represent an original depositional feature, i.e. bedding and diagenetic compaction, with development of a slaty cleavage parallel to bedding. The very hard nature of the specimen, its horny aspect and subconciodal to jagged fracture (Fig, 3C, arrowed, D) when struck for the purpose of obtaining material for thin sections is consistent with it being a hornfels. Furthermore, the presence of very small needle-like crystals of tourmaline and the lack of significant growth of muscovite, biotite, cordierite and andalusite (Fig. 4) suggest that it is a tourmalinised, hornfelsed slate produced by relatively low grade contact metamorphism following earlier low grade regional metamorphism of a finely laminated mudstone. The complexity of quartz veining, which appears to represent at least two mineralisation events, and possible brecciation of first phase quartz veining as seen in Fig. 3A, also support this conclusion.

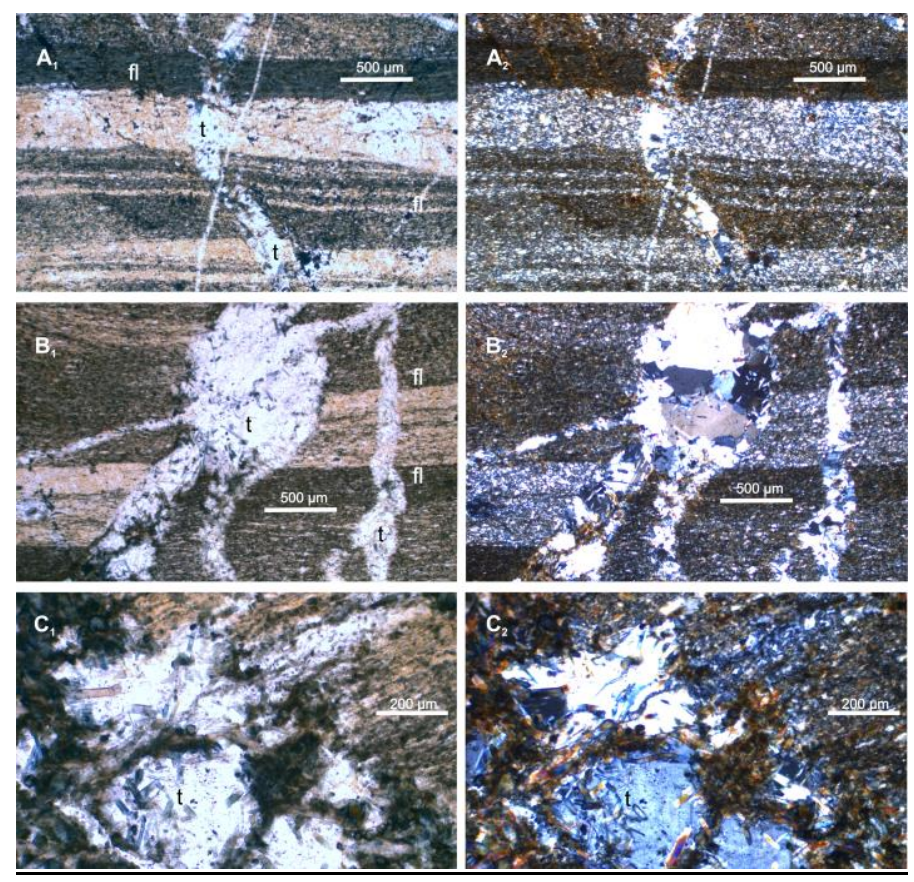

Fig. 4. Photomicrographs of thin sections prepared from fragments taken from IWCMS : 2018.47 and accessioned under the same number in, $A_{1}, B_{1}$ and $C_{1}$ plain polarized light, and $A_{2}, B_{2}$ and $C_{2}$ under crossed polars. Note the very fine grain size, dark clay rich and light quartz rich laminations, and displacement of laminations in B. C, a higher magnification view showing needle-like crystals of tourmaline in quartz. Note also cross cutting quartz veins in $A$ and $B$ suggesting at least two phases of mineralisation. Abbreviations: $\mathrm{fl}$, fine laminations; $\mathrm{t}$, small, needle-like crystals of tourmaline visible in quartz veins. 


\section{Constraints on transport}

The species responsible for transport of IWCMS : 2018.47 is unknown. However, conifers were a major component of Early Cretaceous floras and the conifer Pseudofrenelopsis parceramosa is a significant element of the Wessex Formation flora (Oldham, 1976; Watson and Alvin, 1996). Other elements including ferns and cycads were abundant but more diminutive and it is, therefore, reasonable to assume that coniferous roots were the mode of transport. An average pine-wood density of $0.470 \mathrm{~kg} / \mathrm{m}^{3}$ has been calculated with reference to 20 extant conifer species (Table 1 ). Thus $1 \mathrm{~m}^{3}$ of wood displaces approximately 0.47 metric tonnes of fresh water, dependent upon the wood's actual density, and is capable of supporting a ballast weight of about 0.53 metric tonnes before reaching neutral buoyancy. A recent study has demonstrated a linear relationship between stump diameter and root volume for the Norway spruce, Picea abies, (Smith et al., 2014, p. 3285, Fig. 7a). Using their data a tree with a stump diameter of c. $300 \mathrm{~mm}$ would provide a root volume of c. $100 \mathrm{~L}$. This, assuming the average pine-wood density discussed above, would be capable of accommodating a ballast weight of $24.9 \mathrm{~kg}$ before reaching neutral buoyancy, and considerably more if any substantial portion of the trunk remained. Similarly, a stump diameter of $475 \mathrm{~mm}$ yielding a root volume of $200 \mathrm{~L}$ is capable of accommodating twice the ballast weight of a $300 \mathrm{~mm}$ stump. These figures are, of course, theoretical regarding transport of the Wessex Formation clast described here due to uncertainties concerning the density of the wood and the root volume of the species concerned. Furthermore, they take no account of any waterlogging of the stump. However, they do serve to show that it is highly probable that a coniferous tree with a trunk well within the maximum diameter of logs observed in the Wessex Formation $(\sim 500 \mathrm{~mm})$, most of which would have had a significantly larger diameter before compaction and fossilisation, could have transported a clast weighing $20 \mathrm{~kg}$.

$\begin{array}{lll}\text { Cedar, eastern red } & \text { Juniperus virginiana } & 0.492 \\ \text { Cedar, northern white } & \text { Thuja occidentalis } & 0.315 \\ \text { Cedar, southern white } & \text { Chamaecyparis thvoides } & 0.352 \\ \text { Cedar, (Tropical American) } & \text { Cedrela odorata } & 0.70 \\ \text { Cedar, western red } & \text { Thuja plicata } & 0.344 \\ \text { Douglas fir (coast type) } & \text { Pseudotsuga taxifolia } & 0.512 \\ \text { Douglas fir (mountain type) } & \text { Pseudotsuga taxifolia } & 0.446 \\ \text { Fir, balsam } & \text { Abies balsamea } & 0.414 \\ \text { Fir, silver } & \text { Abies amabilis } & 0.415 \\ \text { Pine, eastern white } & \text { Pinus strobus } & 0.373 \\ \text { Pine, jack } & \text { Pinus banksiana } & 0.461 \\ \text { Pine, loblolly } & \text { Pinus taeda } & 0.593 \\ \text { Pine, longleaf } & \text { Pinus palustris } & 0.638 \\ \text { Pine, pitch } & \text { Pinus rigida } & 0.542 \\ \text { Pine, red } & \text { Pinus resinosa } & 0.507 \\ \text { Pine, shortleaf } & \text { Pinus echinata } & 0.584 \\ \text { Redwood } & \text { Sequoia sempervirens } & 0.436 \\ \text { Spruce, black } & \text { Picea mariana } & 0.428 \\ \text { Spruce, red } & \text { Picea rubra } & 0.413 \\ \text { Spruce, white } & \text { Picea glauca } & 0.431\end{array}$

Table 1. Wood density, $\mathrm{kg} / \mathrm{m}^{3}$, of 20 extant coniferous trees. Average 0.470 . Data from California University Dominguez Hills at http://www5.csudh.edu/oliver/chemdata/woods.htm 


\section{Origin of the clast}

Uplift of the Cornubian Massif took place during the Early Cretaceous and resulted in the spread of rivers across the underlying Purbeck Group during the late Berriasian - early Valanginian (Allen and Wimbledon, 1991). In Dorset, to the west of the eastern coastal area, coarse sediments represent a braid-plain whereas in Swanage Bay and on the Isle of Wight finer grained deposits represent meander-plain facies (Radley and Coram, 2011; Sweetman, 2011). In Dorset the Wessex Formation thins rapidly westward. In Swanage Bay it is c. $700 \mathrm{~m}$ thick whereas at Durdle Door, a little over $22 \mathrm{~km}$ to the west, it is just $65 \mathrm{~m}$ thick. However, this thinning may be exaggerated by faulting and overstepping by later Cretaceous strata (Arkell, 1947).

As on the Isle of Wight, the Wealden strata of Dorset were deposited on the downthrown side of the Purbeck-Isle of Wight structure reflecting reactivation of basement faults. In Dorset this is dominated by the Isle of Purbeck monocline and the Ridgeway-Abbotsbury fault complex (Stoneley, 1982). A number of workers have suggested the presence of an Early Cretaceous rollover anticline on the downthrown side of the Purbeck part of the Purbeck-Isle of Wight structure that may have restricted the Wealden alluvial system to a narrow east-west trending valley (Selley and Stoneley, 1987; Underhill and Stoneley, 1998). If this were the case it strongly suggests that the Isle of Wight clast is derived from a Cornubian source. That this may have been a secondary source rather than a primary one is further discussed below. However, it is noteworthy that large Palaeozoic clasts of the sort described here have not yet been recorded in coarse braid-plain deposits occurring in Dorset. Nevertheless, these deposits, including the Coarse Quartz Grit, do incorporate smaller Palaeozoic clasts, including those of hornfels that Arkell (1947) considered to be derived directly from Cornubian source rocks. Furthermore, angular grits exposed in Swanage Bay that closely resemble residues remaining after the extraction of china clay also suggest that active erosion of the Dartmoor Granite, and therefore the surrounding metamorphic aureole, was taking place during the Early Cretaceous (pers. obs.). White, (1921) also records a well-polished pebble from one of the plant debris beds exposed on the south-east coats of the Isle of Wight which he considered to be "reptilian stomach stone". A colleague, Dr. H. H. Thomas, described it as "a highly tourmalinized quartzose breccia, composed of fragments of tourmaline-hornfels and tourmalinized fine-grained quartzite cemented with secondary quartz through which tourmaline needles run in all directions". He adds that breccias of a similar nature occurring in superficial deposits are usually attributed to a "West of England" source (White, 1921). The specimen is now in the collections of the British Geological Survey with accession number E.12008.

During the Early Cretaceous Cornubia was an upland area primarily comprising folded Devonian and Carboniferous rocks that extended from Devon to the Isles of Scilly (Fig. 2). It was fringed to the east by Permo-Triassic red-bed and Jurassic strata (Allen, 1981). The Early Triassic (Olenekian) Budleigh Salterton Pebble Beds (at the time of writing the status of this name is under review by the British Geological Survey) of the Chester Formation (Ambrose et al., 2014) are currently exposed in the region of the town of the same name. This is located c. $115 \mathrm{~km}$ to the west of the locality from which IWCMS : 2018.47 was recovered. They comprise brown, horizontallybedded conglomerates with subordinate lenticular beds of trough cross-bedded pebbly sand and sand (Smith, 1990; Smith and Edwards, 1991). The Pebble Beds are composed of well-rounded pebbles, cobbles and boulders in a coarse to fine granulestone and silty sandstone matrix. The clasts are mainly (84 to 90 per cent) metaquartzite, together with porphyry, vein quartz, fine-grained conglomerate with quartz clasts and tourmalinite (Smith and Edwards, 1991; Radley and Coram, 
2015 and references therein). The origin of these clasts is still a matter of some debate but clast imbrication suggests a northerly direction of flow for waters responsible for deposition of the Triassic pebble beds of south west England. Many of the Budleigh Salterton Pebble Beds clasts have lithologies closely resembling metaquartzites occurring in the lower part of the Early Ordovician Grès Armoricain of Brittany suggesting that this is the source of the majority (Smith and Edwards, 1991; Radley and Coram, 2015 and references therein). However, the Budleigh Salterton Pebble Beds also include clasts of lithologies incompatible with this source and which suggest that some of these may have been derived from other sources. Data relating to heavy minerals and zircon ages (Morton et al., 2016) now suggest that the Budleigh Salterton Pebble principally comprise Armorican, Cadomian-age material, with metasedimentary rocks of this age being important during its deposition.

Some $10 \mathrm{~km}$ east of Budleigh Salterton Permian breccias and conglomerates containing locally derived clasts, including those of hornfels are also currently exposed. These comprise the Alphington Breccia Formation (Bristow and Scrivener, 1984). Clasts in these are less well rounded than those occurring in the Budleigh Salterton Pebble Beds but provide an alternative source for IWCMS : 2018.47. The petrology of the Wessex Formation clast precludes the Grès Armoricain of Britany as its primary source. However it does not preclude primary derivation from the metamorphic aureole associated with the Dartmoor granite and reworked from Permian deposits, nor does it preclude primary derivation from Armorican, Cadomian-age material reworked from Triassic conglomerates such as the Budleigh Salterton Pebble Beds. An alternative, although entirely hypothetical source may have been recycling of a locally derived hornfels clast from the proximal part of a Wealden fan that is no longer preserved. Age determination beyond the scope of this study is required to determine with certainty whether IWCMS : 2018.47 was primarily derived from an Armorican or Cornubian source. In either case is seems probable that it is a clast reworked from Permian or, perhaps more likely in view of the observed rounding, Triassic strata fringing the Cornubian Massif.
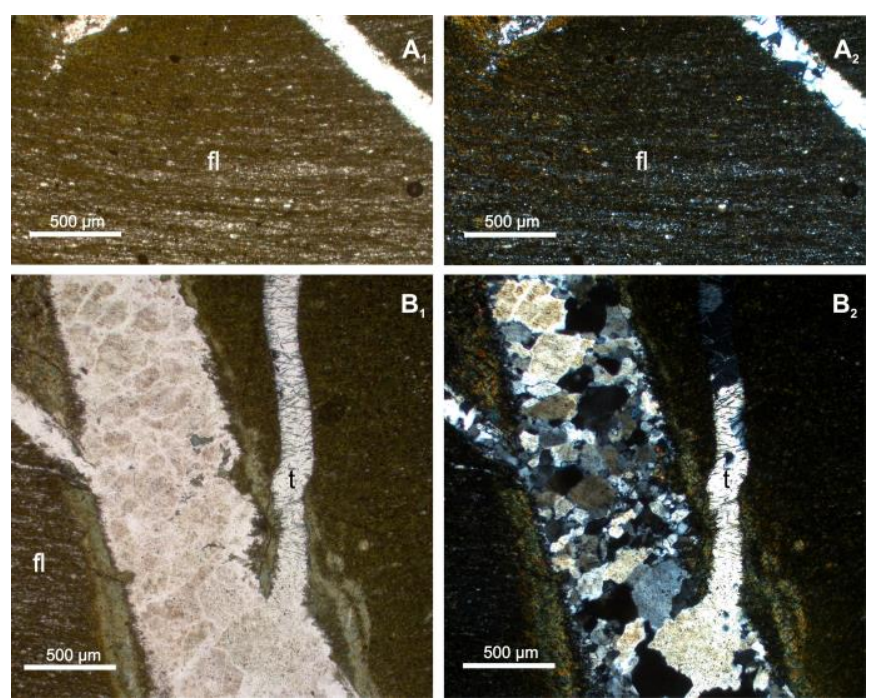

Fig. 5. Photomicrographs of thin sections, in University of Portsmouth collections, prepared from well-rounded hornfels clasts collected directly from an exposure of the Budleigh Salterton Pebble Beds. In, $A_{1}$ and $B_{1}$ plain polarized light, and $A_{2}$ and $B_{2}$ under crossed polars. Note fine laminations $(\mathrm{fl})$, in $A$ and $B$, and cross cutting quartz veins with tourmaline in $B$. Abbreviations: $\mathrm{fl}$, fine laminations; $t$, small needle-like crystals of tourmaline visible in quartz veins. 
By way of comparison a small number of hornfels clasts (that show a similar degree of rounding to the Wessex Formation clast) were collected directly from an exposure of the Budleigh Salterton Pebble Beds and thin sections prepared from them. While, as expected, no precise lithological match was found these clasts show remarkable similarity to the Wessex Formation clast lithology. Photomicrographs obtained from two thin sections are provided in Fig. 5. Both specimens are very fine-grained, finely laminated, and display the same cross cutting quartz veins and small needle-like tourmaline crystals observed in IWCMS : 2018.47. This supports derivation of the Wessex Formation clast from the Budleigh Salterton Pebble Beds but does not preclude derivation from another source.

Clasts occurring in the Budleigh Salterton Pebble Beds, and the Permian conglomerates and breccias of Devon, are generally iron stained and reddish-brown when in situ and shortly after release from the host rock. The Wessex Formation clast bears no trace of staining but it is impermeable and any surface staining, were it to have been derived from one of these sources, would be readily removed during transport. Should any of the original surface staining have remained after the clast was deposited on the Wessex Formation floodplain, having been shielded from abrasion by enclosing roots, it may well have persisted while exposed in oxidising conditions there but it would have been secondarily reduced after incorporation into the plant debris bed from which it was recovered (Sweetman and Insole, 2010). Lack of surface staining does not, therefore, preclude derivation from a Permian or Triassic source in south-east Devon.

\section{Conclusions}

The occurrence of a very large metamorphic clast in the Wessex Formation of the Isle of Wight demonstrates that very substantial runoff from the Cornubian Massif occurred at times during the Early Cretaceous. This was sufficient to transport large floating objects derived from at least 110 $\mathrm{km}$ to the west across a braid-plain extending for at least $60 \mathrm{~km}$ and then a further $50 \mathrm{~km}$ or more across a meander-plain to what is now the Isle of Wight. Such long distance transport of large floating objects has been postulated for some time. White (1921) suggested this in connection with logs known as the Pine Raft occurring on the south-west coast of the Isle of Wight at Hanover Point, which appear to have been stranded on a sandy point bar. Stewart (1981) also proposed this in connection with genesis of the Wessex Formation plant debris beds, although an alternative mode of deposition of these (Sweetman and Insole, 2010) is now generally accepted. Nevertheless, this is the first concrete evidence for such high volume runoff and associated transport of large floating objects because logs comprising the Pine Raft may have been derived locally. That such transport was possible suggests that some dinosaur remains recovered from the Wessex Formation may have originated as floating carcases sourced from as far away as the Cornubian Massif. This must now be taken into account when considering the palaeoecology of the Wessex Formation dinosaurs as some may have been upland residents rather than residents of, or visitors to floodplain environments.

Smaller extrabasinal clasts of Palaeozoic aspect occurring in the Wessex Formation, most of which are currently interpreted as gastroliths, may also have been obtained by dinosaurs from Permiaan and Triassic host-rocks exposed on the margins of the Cornubian Massif. Others, and perhaps the majority, were most probably obtained from the closer occurrence of coarse-grained braid-plain deposits in Dorset. This is supported by petrographic work currently in progress which 
shows that some Wessex Formation gastroliths comprise silicified wood of Jurassic, Purbeck Group aspect (Megan Jacobs, University of Portsmouth, pers. comm. 2019).

\section{Acknowledgements}

We are grateful to Geoff Long for preparation of thin sections and to the University of Portsmouth for funding this; to Dean Bullen, University of Portsmouth, for his help with petrology; and to Andy Gale, University of Portsmouth, for the collection of hornfels clasts from the Budleigh Salterton Pebble Beds, and for discusions with him and David Martill, University of Portsmouth, regarding the origin of extrabasinal clasts in the Wessex Formation. We are grateful to Megan Jacobs, University of Portsmouth for information concerning Wessex Formation gastrolith lithologies. Martin Munt and Alex Peaker, IWCMS, are thanked for their curatorial assistance. Andy Gale and two anonymous referees are thanked for their detailed reviews which have greatly improved sections of the manuscript

\section{References}

Allen, P. 1981. Pursuit of Wealden models. Journal of the Geological Society, London 138, 375-405. Allen, P. 1998. Purbeck-Wealden (early Cretaceous) climates. Proceedings of the Geologists' Association 109, 197-236.

Allen, P. and Wimbledon, W.A., 1991. Correlation of NW European Purbeck-Wealden (nonmarine Lower Cretaceous) as seen from the English type-areas. Cretaceous Research 12, 511-526.

Ambrose, K., Hough, E., Smith, N. J. P. and Warrington, G. 2014. Lithostratigraphy of the Sherwood Sandstone Group of England, Wales and south-west Scotland. Geology and regional geophysics directorate research report RR/14/01. British Geological Survey, Nottingham, 50 pp.

Arkell, W. J. 1947. The geology of the country around Weymouth, Swanage, Corfe and Lulworth. Memoir of the Geological Survey, Sheets 341, 342, 343, with small portions of Sheets 327, 328, 329 (England and Wales). HMSO, London, xii + 386 pp., 19 pls.

Batten, D. J. 2011. Wealden Geology. In D.J. Batten (Ed.), English Wealden Fossils. Palaeontological Association Field Guide to Fossils 14, pp. 7-14.

Bennett, M. R., Doyle, P. and Mather, A. E. 1996. Dropstones: their origin and significance. Palaeogeography, Palaeoclimatology, Palaeoecology 121, 331-339.

Bristow, C. R. and Scrivener, R. C. 1984. The stratigraphy and structure of the Lower New Red Sandstone of the Exeter district. Proceedings of the Ussher Society 6, 68-74.

Chadwick, R. A. 1985. End Jurassic-Early Cretaceous sedimentation and subsidence (late Portlandian to Barremian), and the late-Cimmerian unconformity. In: Whitaker A. (Ed.), Atlas of onshore sedimentary basins in England and Wales: post-Carboniferous tectonics and stratigraphy. Blackie, Glasgow, pp. 52-56.

Durrance, E. M. and Laming, D. J. C. (Eds.). 1982. The Geology of Devon. University of Exeter Press, $346 \mathrm{pp}$.

Harding, I. C. 1986. An Early Cretaceous dinocyst assemblage from the Wealden of southern England. Special Papers in Palaeontology 35, 95-109.

Hughes, N. F. and McDougall, A. D. 1990. New Wealden correlation for the Wessex Basin. Proceedings of the Geologists' Association 101, 85-90.

Martill, D. M. and Naish, D. 2001 (Eds). Dinosaurs of the Isle of Wight. Palaeontological Association, London, Field Guides to Fossils, 10. Palaeontological Association London, 433 pp. 
Mayne, R. G. 1854. An Expository Lexicon of the Terms, Ancient and Modern, in Medical and General Science. J. Churchhill, London, $1504 \mathrm{pp}$.

Morton, A., Knox, R. and Frei, D. 2016. Heavy mineral and zircon age constraints on provenance of the Sherwood Sandstone Group (Triassic) in the eastern Wessex Basin, UK. Proceedings of the Geologists' Association 127, 514-526.

Oldham, T. C. B. 1976. Flora of the Wealden plant debris beds of England. Palaeontology 19, 437502.

Pond, S., Lockley, M. G., Lockwood, J. A. F., Breithaupt, B. H. and Matthews, N. A. 2014. Tracking Dinosaurs on the Isle of Wight: a review of tracks, sites, and current research. Biological Journal of the Linnean Society 113, 737-757.

Radley, J. D. 1993. A Derived Lower Jurassic Clast from the Wealden Group (Lower Cretaceous) of the Isle of Wight, Southern England. Proceedings of the Geologists' Association 104, 71-73.

Radley, J. D. and Coram, R. A. 2011. The Wealden of Dorset. In: Batten, D. J. (Ed.) English Wealden Fossils. Palaeontological Association field guide to fossils 14. The Palaeontological Association London, pp.79-84.

Radley, J. D. and Coram, R. A. 2015. Derived Skolithos pipe rock in the Budleigh Salterton Pebble Beds (Early Triassic, East Devon, UK). Proceedings of the Geologists' Association 126, 220-225.

Radley, J. D., Gale, A. S. and Barker, M. J. 1998. Derived Jurassic fossils from the Vectis Formation (Lower Cretaceous) of the Isle of Wight, southern England. Proceedings of the Geologists' Association 109, 81-91.

Selley, R. C. and Stoneley, R. 1987. Petroleum habitat in south Dorset. In: Brooks, J. and Glennie, K. (Eds). Petroleum geology of North West Europe. Graham and Trotman, London, pp. 139-148.

Smith, S. A. 1990. The sedimentological and accretionary styles of an ancient gravel-bed stream: the Budleigh Salterton Pebble Bed (Lower Triassic), southwest England. Sedimentary Geology 67, 199-219.

Smith, S. A. and Edwards, R. A. 1991. Regional sedimentological variations in Lower Triassic fluvial conglomerates (Budleigh Salterton Pebble Beds), southwest England: some implications for palaeogeography and basin evolution. Geological Journal 26, 65-83

Smith, A., Astrup, R., Raumonen, P., Liski, J., Krooks, A., Kaasalainen, S., Åkerblom, M. and Kaasalainen, M. 2014. Tree root system characterization and volume estimation by terrestrial laser scanning and quantitative structure modelling. Forests 5, 3274-3294; doi:10.3390/ 55123274

Stewart, D. J. 1978. The sedimentology and palaeoenvironment of the Wealden Group of the Isle of Wight, southern England. Unpublished PhD thesis, Portsmouth University, 347 pp. + appendices.

Stewart, D. J. 1981. A field guide to the Wealden Group of the Hastings area and Isle of WIGHT. In: Elliot, T. (Ed.), Field guide to modern and ancient fluvial systems in Britain and Spain: International Fluvial Conference, Keele University, 3.1-3.31.

Stoneley, R. 1982. The structural development of the Wessex Basin. Journal of the Geological Society, London 139, 543-554.

Sweetman, S. C. 2011. The Wealden of the Isle of Wight. In Batten, D. J. (Ed.) English Wealden Fossils. Palaeontological Association field guide to fossils 14. The Palaeontological Association London, pp. 52-78.

Sweetman, S. C. and Insole, A. N. 2010. The plant debris beds of the Early Cretaceous (Barremian) Wessex Formation of the Isle of Wight, southern England: their genesis and paleontological significance. Palaeogeography, Palaeoclimatology, Palaeoecology 292, 409-424. 
Sweetman, S. C. and Underwood, C. J. 2006. A neoselachian shark from the non-marine Wessex Formation (Wealden Group: Early Cretaceous, Barremian) of the Isle of Wight, southern England. Palaeontology 49, 457-465.

Underhill, J. R. 2002. Evidence for structural controls on the deposition of the Late Jurassic-Early Cretaceous Purbeck Limestone Group, Dorset, southern England. In: Milner, A. R. and Batten, D. J. (Eds.). Life and Environments in Purbeck Times. Special Papers in Palaeontology 68. The Palaeontological Association London, pp. 21-40.

Underhill, J. R and Stoneley, R. 1998. Introduction to the development, evolution and petroleum geology of the Wessex Basin. In: Underhill, J. R. (Ed.), Development, evolution and petroleum geology of the Wessex Basin. Geological Society, London, Special Publication 133, pp. 1-18.

Watson, J.and Alvin, K.L., 1996. An English Wealden floral list, with comments on possible environmental indicators. Cretaceous Research 17, 5-26.

White, H. J. O. 1921. A short account of the geology of the Isle of Wight. District memoir of the Geological Survey of Great Britain (England and Wales). Her Majesty's Stationary Office, 246 pp.

Wings, O. 2007. A review of gastrolith function with implications for fossil vertebrates and a revised classification. Acta Palaeontologica Polonica 52, 1-16. 